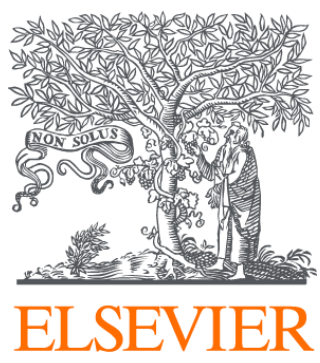

Since January 2020 Elsevier has created a COVID-19 resource centre with free information in English and Mandarin on the novel coronavirus COVID-

19. The COVID-19 resource centre is hosted on Elsevier Connect, the company's public news and information website.

Elsevier hereby grants permission to make all its COVID-19-related research that is available on the COVID-19 resource centre - including this research content - immediately available in PubMed Central and other publicly funded repositories, such as the WHO COVID database with rights for unrestricted research re-use and analyses in any form or by any means with acknowledgement of the original source. These permissions are granted for free by Elsevier for as long as the COVID-19 resource centre remains active. 


\section{Index to Volume 8, 2006}

\section{Author Index}

Amorim, F. V. 379

Baral, R. M. 23

Baral, R. 91

Barth, A. 69

Barrett, K. A. 372

Barrs, V. R. 23, 91

Barrs, V. R. D. 327, 412

Baptiste, K. 69

Basaraba, R. J. 353

Baumgärtner, W. 424

Beatty, J. A. 91, 327, 412

Begara-McGorum, I. M. 129

Bennett, N. 73

Bernardini, M. 424

Berndtsson, L. T. 207

Bessant, C. 145

Bolus, R. R. 261

Bradshaw, J. M. 234

Brain, P. H. 91

Brearley, M. 169

Brewer, M. M. 85

Brewer, M. 315

Brunnberg, L. 227

Brunt, J. 85, 213

Bueno, D. F. 345

Buffington, C. A. T. 261, 361

Burney, D. 85

Caldanaro, R. J. 292

Cambier, C. 45

Capucchio, M. T. 340

Case, J. B. 111

Casella, M. 119

Castagnaro, M. 424

Catt, M. J. 23

Cavana, P. 340

Chase, K. 363

Chen, S. C. A. 23

Chew, D. J. 261

Chomel, B. 111

Chretin, J. D. 285
Cizinauskas, S. 243

Claus, M. A. 184

Clercx, C. 45

Coe, R. J. 15

Côté, E. 372

Crawford, P. C. 184

D'Ippolito, P. 420

Delattre, L. 45

de Lahunta, A. 63

Delvaux, F. 45

de Matos Gomes, A. 345

de Melo Ocarino, N. 345

Dennis, R. 63

de Oliveira, T. S. 345

De Santis-Kerr, A. C. 292

Doherr, M. 243

Dow, S. W. 400

Dumon, H. J. W. 309

Eberhardt, J. M. 164

Ellersieck, M. 363

Else, R. W. 129

Englund, L. 207

Evans, R. H. 363

Evrard, B. 45

Farca, A. M. 340

Ferreira, A. M. R. 379

Fettman, M. J. 73

Foley, J. E. 111

Foley, J. 55

Fonseca, A. B. M. 379

Forterre, F. 227

Foster, D. J. 412

Fritsch, G. 227

Fukushima, F. B. 345

Gandini, G. 243

Gary, A. T. 321

Garosi, L. 63

Gelain, M. E. 389
Gibbon, K. J. 141

Glickman, L. T. 292

Glickman, N. W. 292

Goodfellow, M. 169

Greco, D. S. 73

Griffin, B. 85

Grint, N. J. 15

Gruffydd-Jones, T. J. 145

Gunn-Moore, D. A. 129, 145, 192, 234

Gunn-Moore, F. J. 234

Guptill, L. 213

Gustin, P. 45

Hackett, T. B. 321

Hawley, J. 85

Hayes, A. 169

Head, E. 234

Heininger, K. 363

Henley, W. E. 145

Holst, B. S. 207

Hurley, K. 55

Ihrke, P. 327

Iwasaki, T. 302

Jaggy, A. 243

Jantulik, B. 135

Jaspart. S. 45

Jensen, W. A. 85, 353

Kadoya, M. 302

Kaiser, S. 227

Kirk, C. 73

Kirschvink, N. 45

Kley, S. 119

Kipar, A. 69

Kohn, B. 254

Kordick, D. L. 213

Krockenberger, M. B. 23, 327

Kudrak, S. 213

Kurian, J. R. 141 
Langley-Hobbs, S. 197

Lappin, M. R. 7, 85, 158, 164, 213, $315,321,353,400$

Larson, B. T. 363

Lawler, D. F. 363

Leemans, J. 45

Leibold, W. 254

Levy, J. K. 184, 279

Lewis, H. B. 292

Li, Q. 363

Linden, T. 254

Litster, A. 105

Litster, A. L. 177

Lyons, L. A. 357

MacDonald, K. 184

Maggs, D. J. 357

Malik, R. 23, 135, 327

Mardell, E. J. 269

Martin, L. J. M. 309

Martin, P. 23, 91

Mathes, M. 73

Matiasek, K. 227

May, J. M. 145

McKellar Stewart, K. 327

McVee, J. 234

Meli, M. 389

Metcalfe, S. S. 23

MeWhirter, C. 23

Mills, P. C. 105

Milne, E. M. 192

Mitchell, D. H. 23

Momoi, Y. 302

Moore, G. E. 292

Murison, P. J. 15

Murphy, S. 169

Neal, K. 164

Negrin, A. 424

Nguyen, P. 309

Nicholson, W. 111
Nicoli, S. 420

Nishii, N. 349

Norman, B. C. 372

Norris, J. 135

Ohtsuka, H. 349

Palacios, S. 207

Paltrinieri, S. 389

Pearce, L. K. 315

Pearson, A. E. W. 15

Pearson, G. R. 234

Pedersen, N. C. 55

Pesavento, P. A. 55

Pesteanu-Somogyi, L. D. 1

Peterson, M. E. 73

Poland, A. 55

Pope, S. 327

Porter, M. 158

Pressler, B. M. 1

Radecki, S. J. 158

Radecki, S. V. 7, 315

Radzai, C. 1

Raghavan, M. 292

Rah, H. C. 357

Reed, N. 129, 192

Reinacher, M. 69

Renström, L. 207

Reusch, C. E. 119

Richmond, H. L. 321

Riley, A. 85

Rogers, K. 145

Satyaraj, E. 363

Scase, T. 63

Schantz, P. M. 292

Scherk, M. 291

Scorza, A. V. 7

Sebring, R. W. 158

Serakides, R. 345
Sewell, A. C. 290

Shackelford, T. 164

Shales, C. J. 197

Siliart, B. 309

Simpson, K. E. 192

Snaps, F. 45

Sorenmo, K. U. 177

Sousa, C. A. 327

Souza, H. J. M. 379

Sparkes, A. H. 145, 269, 291

Strom, T. L. 141

Sugimoto, N. 349

Summers, B. 63

Suzuki, K. 349

Swift, N. 412

Takahashi, K. 349

Tasker, S. 321

Tomek, A. 243

Trepanier, L. A. 141

Tucker, S. J. 184

Veir, J. 158

Veir, J. K. 400

Vittone, V. 340

Wagner, K. A. 141

Wallace, J. L. 279

Walton, S. 327

Weiss, D. J. 203

Westropp, J. L. 261

White, J. 135

White, J. D. 91

Wright, Z. M. 285

Wigney. D. I. 23

Yuki, M. 349

Zatelli, A. 420 


\section{Subject Index}

A big impact, and a big 'thank you' ... 291

A questionnaire-based study of gestation, parturition and neonatal mortality in pedigree breeding cats in the UK 145

A retrospective study of ${ }^{90}$ Strontium plesiotherapy for feline squamous cell carcinoma of the nasal planum 169

Adverse effects of EMLA (lidocaine/prilocaine) cream and efficacy for the placement of jugular catheters in hospitalized cats 141

Ageing changes in cat brains demonstrated by $\beta$-amyloid and AT8-immunoreactive phosphoryl ated tau deposits 234

American Association of Feline Practitioners 2006 Panel report on diagnosis, treatment, and prevention of Bartonella spp. infections 213

Aplastic anemia in cats - clinicopathological features and associated disease conditions 1996-2004 203

Assessment of the influence of surgical technique on postoperative pain and wound tenderness in cats following ovariohysterectomy 15

Bilateral, hypertrophic neuritis of the brachial plexus in a cat: magnetic resonance imaging and pathological findings 63

Characterisation of the signalment, clinical and survival characteristics of 41 cats with mast cell neoplasia 177

Clinical evaluation of multimodal environmental modification (MEMO) in the management of cats with idiopathic cystitis 261

Clinical, cytological and histopathological evaluation of mammary masses in cats from Rio de Janeiro, Brazil 379

Comparison of a low carbohydrate-low fiber diet and a moderate carbohydrate-high fiber diet in the management of feline diabetes mellitus 73

Crusted scabies (sarcoptic mange) in four cats due to Sarcoptes scabiei infestation 327

Diagnosis and treatment of a feline oral mast cell tumor 285

Disseminated Mycobacterium avium infection in young cats: overrepresentation of Abyssinian cats 23

Dorso-medial antebrachiocarpal luxation with radio-ulna luxation in a domestic shorthair 197

Effect of sample type, and timing of assay, on feline blood potassium concentration 192
Effects of a single dose of an intranasal feline herpesvirus 1, calicivirus, and panleukopenia vaccine on clinical signs and virus shedding after challenge with virulent feline herpesvirus 1158

Efficacy of a combination of febantel, pyrantel, and praziquantel for the treatment of kittens experimentally infected with Giardia species 7

Enterolithiasis in a cat 349

Evaluation of a commercial in-house test kit for the semi-quantitative assessment of microalbuminuria in cats 269

Evaluation of a novel immunotherapy for treatment of chronic rhinitis in cats 400

Feline cholecystitis and acute neutrophilic cholangitis: clinical findings, bacterial isolates and response to treatment in six cases 91

Feline primary hyperoxaluria 290

Home monitoring of the diabetic cat 119

Idiopathic hypertrophic osteopathy in a cat 345

Inhaled fluticasone reduces bronchial responsiveness and airway inflammation in cats with mild chronic bronchitis 45

Immunoglobulin concentrations in feline colostrum and milk, and the requirement of colostrum for passive transfer of immunity to neonatal kittens 184

Interstitial nephritis in cats inoculated with Crandell Rees feline kidney cell lysates 353

Intracranial neoplasia in 61 cats: localisation, tumour types and seizure patterns 243

Invited commentry on 'The aging feline kidney: a model mortality antagonist?' 361

Lack of genetic association among coat colors, progressive retinal atrophy and polycystic kidney disease in Persian cats 357

Late onset cerebellar degeneration in a middle-aged cat 424

Natural FCoV infection: cats with FIP exhibit significantly higher viral loads than healthy infected cats 69

Parathyroid adenocarcinoma in a nephropathic persian cat 340

Plasma histamine concentration and histamine detection in peripheral blood eosinophils in cats 302 
Platelet-bound antibodies detected by a flow cytometric assay in cats with thrombocytopenia 254

Population characteristics of feral cats admitted to seven trap-neuter-return programs in the United States 279

Prevalence of feline infectious peritonitis in specific cat breeds 1

Prevalence and risk factors for Giardia and coccidia species of pet cats in 2003-2004 292

Prevalence of Bartonella henselae antibodies in serum of cats with and without clinical signs of central nervous system disease 315

Prevalence of Bartonella species, haemoplasma species, Ehrlichia species, Anaplasma phagocytophilum, and Neorickettsia risticii DNA in the blood of cats and their fleas in the United States 85

Prevalence of antibodies against feline coronavirus and Chlamydophila felis in Swedish cats 207

Prevalence of selected infectious disease agents in cats from Arizona 164

Proximal ureteral ectopia causing hydronephrosis in a kitten 420

Serological survey of vector-borne zoonotic pathogens in pet cats and cats from animal shelters and feral colonies 111
Spontaneous hormonal variations in male cats following gonadectomy 309

Surgical approach for tentorial meningiomas in cats: a review of six cases 227

Survival of Mycoplasma haemofelis and 'Candidatus Mycoplasma haemominutum' in blood of cats used for transfusions 321

Suspected clindamycin-associated oesophageal injury in cats: five cases 424

The aging feline kidney: a model mortality antagonist? 363

Unusual histiocytic disease in a Somali cat 129

Using urea dilution to standardise cellular and non-cellular components of pleural and bronchoalveolar lavage (BAL) fluids in the cat 105

Virulent systemic feline calicivirus infection: local cytokine modulation and contribution of viral mutants 55

Whole blood cytokine profiles in cats infected by feline coronavirus and healthy non-FCoV infected specific pathogen-free cats 389

Wide-complex tachycardia associated with severe hyperkalemia in three cats 372

Wound Cat 135 